\title{
Protein-Tyrosine Kinase 2-Beta
}

National Cancer Institute

\section{Source}

National Cancer Institute. Protein-Tyrosine Kinase 2-Beta. NCI Thesaurus. Code C17978.

Protein-tyrosine kinase 2-beta (1009 aa, $\sim 116 \mathrm{kDa}$ ) is encoded by the human PT K2B gene. This protein plays a role in tyrosine phosphorylation, signal transduction and the regulation of many cellular processes including apoptosis, cell migration, cell proliferation and cell adhesion. 